\title{
Do entrepreneurial characteristics and education influence start-up potentials among undergraduates? Evidence from a developing country
}

\author{
Caleb M. Adelowo, Oluwatosin E. Ilevbare, Jhalukpreya Surujlal
}

\begin{abstract}
A B S T R A C T
Objective: Entrepreneurship education offers plausible policy options to curtail the consistent rise in youth unemployment in Nigeria. Understanding students' entrepreneurial characteristics will assist university administrators, policymakers, scholars and practitioners to deliver contents that stimulate their entrepreneurial propensity. This study examines students' entrepreneurial characteristics and how it, together with entrepreneurship education, shapes start-up potential among them in Nigeria.

Research Design \& Methods: The study adapts the personal entrepreneurial characteristics (PECs) scale developed by Management Systems International. Data were collected from three thousand two hundred and seventy-seven ( $N=3$ 277) students from six Nigerian universities. Descriptive and binary logistic regressions were used to estimate important PECs that influenced entrepreneurial interest among the students.

Findings: The results show that majority of the students (92\%) are interested in starting a business, while $36 \%$ of them are already running one form of enterprise. The level of entrepreneurship interest is also high. Generally, the mean/average score for the entire personal entrepreneurial characteristics is high, and specific means were computed for each element of PECs including opportunity seeking, risk-taking, information seeking, systematic planning and monitoring, persuasion and networking, commitment, persistence, demand for efficiency and quality, goal-setting and self-confidence. Binary logistic regression was adopted to examine the influence of PECS on the start-up potentials among the students using the mean scores computed from the PECs as the independent variables. The results show that students with high goal-setting characteristics and opportunity recognition characteristics are highly predisposed to entrepreneurship. The results further showed that students whose parents run businesses and attended entrepreneurship courses are significantly and highly likely to venture into business. Although persuasion and networking, risk-taking and persistence predispose the students to entrepreneurship, the variables were not significant.

Implications \& Recommendations: Entrepreneurship education in the country should therefore be re-designed such that students are adequately profiled to determine the kind of EE best suited for them. For those already practising entrepreneurship, the university administration could establish innovation hubs or labs, as well as business incubators, and organise annual innovation competition to help improve entrepreneurship education outcomes.
\end{abstract}

Contribution \& Value Added: The paper adopts personal entrepreneurial characteristics (PECs) as novel lenses to understand entrepreneurial inclinations among undergraduates in a developing country. Paying particular attention to PEC is important for policymakers and university administrators to improve the policy outcomes of entrepreneurship education policy.

\begin{tabular}{ll}
\hline Article type: & research article \\
Keywords: & Entrepreneurial characteristics, education, undergraduates, job creation, youth \\
JEL codes: & L26, L38
\end{tabular}

$\begin{array}{lll}\text { Received: } 31 \text { May } 2021 & \text { Revised: } 20 \text { July } 2021 & \text { Accepted: } 24 \text { August } 2021\end{array}$

Suggested citation:

Adelowo, C.M., llevbare, O.E., \& Surujlal, J. (2021). Do entrepreneurial characteristics and education influence start-up potentials among undergraduates? Evidence from a developing country. International Entrepreneurship Review, 7(3), 71-82. https://doi.org/10.15678/IER.2021.0703.06 


\section{INTRODUCTION}

Youth unemployment in Nigeria is a serious national concern. With a population of approximately 206 million (NBS, 2020), Nigeria is described as a country with abundant human and natural resources; however, bedevilled with poverty, hunger, as well as stunted economic growth and development. Nigeria currently records 0.36 points and ranks 152 out of 157 countries in the World Bank Group's Human Capital Index $(\mathrm{HCl})$, and was once described as the global capital of poverty despite being acclaimed as the largest economy in Africa (World Bank, 2020). One of the major challenges confronting African countries (Nigeria inclusive) is the high unemployment rate among the youth. Kigotho (2015) revealed that one out of every four university graduates from Africa is unemployed. Specifically, the National Bureau of Statistics (NBS) reported over 16 million unemployed youth (NBS, 2018 ) in Nigeria. The NBS further puts unemployment estimates at $23.13 \%$ during the third quarter of 2018 , suggesting a consistent increment from $18.80 \%$ in the third quarter of 2017 to $22.73 \%$ in the second quarter of 2018 and to $23.1 \%$ in 2019 (NBS, 2020). The estimate implies that over 21 million Nigerians were unemployed in 2018, and given the population growth rate of the country, 30 million new jobs will be needed by 2030 (World Bank, 2019).

It is evident that the majority of this unemployed population are youth, as they make up approximately $46 \%$ of the Nigerian population (NBS, 2018). In a structured region, the large youth population could translate to national assets as they comprise dynamic individuals with vast knowledge, strength and tenacity to drive desirable scientific and technological change in a society. The youth are characterised as techno-savvy, possessing up-to-date skills, innovative prowess, and inventive abilities capable of driving sustainable development. However, in Nigeria, the situation has not been a blessing, but rather a challenge for government and policymakers. This is evident from the number of youth engaged in social vices such as banditry, kidnapping, internet fraud and acts of terrorism (Adebayo, 2013).

Entrepreneurship is a proven strategy to engage the unemployed; this includes not only educated youth, but also the uneducated minds who have the ability to innovate, create ideas, and take on opportunities for economic benefits (Pinelli, 2015). More so, Siyanbola (2011) opined that the wide involvement of youth in entrepreneurial activities is fundamental to stimulating wealth creation, socioeconomic growth and development. Start-ups have been documented to be a game-changer and have the ability to transform a nation from an agrarian community to an industrialised economy. Entrepreneurship has been one of the great management revolutions in recent decades, especially with a focus on innovation and growth of start-ups, science parks, accelerators and incubators, among others. Entrepreneurial activities have been described as a crucial strategy for maintaining economic competitiveness and for achieving long-term economic success. It has also helped to create jobs, improve standards of living, create wealth and pathways to sustainable development (Igwe et al., 2013). As part of the national strategies of developed countries, such as United States and emerging economies like China and other Asian Tigers, to boost their economy, the energy of their youth was harnessed and channelled to encourage self-reliance, innovativeness, as well as scientific and technological breakthroughs for sustainable development. In achieving the aforementioned, governments in lieu ensure the following are in place to provide support, namely provision of a stimulating business environment, adequate and modern infrastructures, facilitation of tech-hubs, start-up capital and grants to budding entrepreneurs as well as entrepreneurial mentoring mechanisms. From the fore-going, promoting entrepreneurship is critical to achieving the goal of the Nigerian government in reducing youth unemployment and poverty, which will, in turn, help to curb so many societal vices. Start-ups have a multiplier effect on the entrepreneur, employees and the nation as a whole. Consequently, government, policymakers, captains of industries and stakeholders around the world are providing supports for young entrepreneurs and start-up firms while also promoting entrepreneurship culture among the youths through education and training. This strategy hopes to improve venture creation potentials through entrepreneurial activities as a way out of the menace of unemployment (Wu \& Wu, 2008). To structure entrepreneurship education more appropriately, and to achieve the desired results, it is im- 
portant to identify and characterise potential entrepreneurs among youths in higher education institutions. Characterising potential entrepreneurs in the system requires a systematic process of eliciting personal entrepreneurial characteristic information from target audiences and juxtaposing them with their entrepreneurial interest. Although several studies have estimated the correlates of entrepreneurial intention among young undergraduates in Nigeria, there appears to be a dearth of research investigating how personal entrepreneurial characteristics influence the behaviour. The purpose of this study is therefore to estimate the influence of personal entrepreneurial characteristics and compulsory entrepreneurship education on entrepreneurial intention among Nigerian undergraduates.

\section{LITERATURE REVIEW}

\section{Personal entrepreneurial characteristics and entrepreneurship development}

Researchers and policymakers have been keen on improving the entrepreneurship potential of the young population in both developed and developing economies to enhance national productivity, improve wealth creation and employment, and promote competitiveness. This has led to the development of several programmes and initiatives targeted at enlisting young people's interest in entrepreneurship, including the introduction of entrepreneurship education in tertiary institutions and sometimes in secondary education to 'catch them young' (Adelowo, Joshua \& llevbare, 2018). Efforts are also being made to improve local and national entrepreneurship ecosystems (GEM, 2020). Perhaps a more efficient way to better entrench entrepreneurship in the youth would be to profile their entrepreneurial characteristics and provide them with targeted theoretical and practical entrepreneurship education (EE). Selection into the EE can then be based on their level of interest and captured entrepreneurial characteristics. Entrepreneurial characteristics are traits and personal competencies that predispose an individual to become successful in venture creation. Some of the several theories and perspectives for understanding and modelling entrepreneurial behaviours or potentials among youths include the theory of reasoned action (Ajzen \& Fishbein; 2005), theory of planned behaviour (Ajzen, 1991) and entrepreneurial orientation dimensions (Lumpkin \& Dess, 1996). These theories have undergone several empirical validations in diverse areas of application, including health and entrepreneurship contexts. The kernel of discussion here is on Ajzen's theory of planned behaviour and its applications to shape entrepreneurship tendencies among the young population. The theory stipulates that intention to perform behaviour of any kind can be predicted accurately from attitudes towards the behaviour, subjective norms and perceived behavioural control (Ajzen, 1991). Ajzen (1991) also affirmed that intention, together with perception of behavioural control, accounts for considerable variance in actual behaviour. Individuals' entrepreneurial dispositions or intention are defined by social, environmental, psychological and physiological factors. The degree of belief that an outcome of a venture will be positive is a strong indication to gravitate an individual towards that behaviour, including entrepreneurship. Furthermore, the subjective norms tend to strengthen the attitude towards a behaviour by providing justifiable and acceptable rationale/approval for the behaviour within a social context. For instance, the formulation of compulsory entrepreneurship education policy since 2006 and the recent provision of technical and financial inducement to young entrepreneurs in Nigeria have reinforced the legitimisation of entrepreneurship and self-employment among young Nigerians. Entrepreneurship is further perceived as a way to overcome massive unemployment in the Nigerian labour market. More so, government's efforts to promote job creation in recent time have focused essentially on formal and informal entrepreneurship skills acquisition and empowerment. Some recent initiatives of government to provide Covid-19 palliatives and social safety nets for youth include Npower, MSME survival fund, conditional cash transfer, and free business registration, among others. These initiatives were developed to remove some business barriers and provide easy access to business registration with the ultimate aim of boosting entrepreneurship and wealth creation in the country. Entrepreneurship is seen as a positive vibe in the society through these initiatives. The third component of the theory of planned behaviour is perceived behavioural control, which relates to how individuals perceive themselves to carry out the behaviour. This connects well with the entrepreneurial competence and capability of individuals to engage in venture creation. This is where entrepreneurship 
education/training comes to play important roles in shaping potential entrepreneurs. Training becomes critical to the development of potential entrepreneurs by exposing them to opportunities, how small businesses are managed and developing their marketing skills (Adelowo, Egbetokun \& James, 2016; Titley \& Anderson-Macdonald, 2015).

Scholars have used personal entrepreneurial characteristics (PECs) or traits to describe and explain the entrepreneurship phenomena over decades (Gartner, 1989; Rauch \& Frese, 2012; Holienka, Holienková \& Gál, 2015). The psychological characteristics of entrepreneurs or enterprising individuals have been generally referred to as PECs. These characteristics tend to underpin the dispositional tendency to engage in entrepreneurial actions and can also be moderated by socio-cultural context, national values and general entrepreneurial ecosystems. Early scholars have examined how PECs define entrepreneurial actions, particularly risk-taking (Knight, 1921), innovativeness, orientation towards achievement, dominance (Schumpeter, 1934; 1942), knowledge and entrepreneurial discovery (Hayek, 1945), and achievement motivation (McClelland, 1961). Management System International and McBer and Company, cited in Reyes et al. (2018), constructed ten main characters of entrepreneurs as presented in Table 1. These personal entrepreneurial characteristics were developed after studying the behaviours of many entrepreneurs in over forty (40) countries for more than five years (USAID, 2011). Entrepreneurship education therefore plays critical roles in instilling/developing these key traits in student and better prepare them for future career.

Table 1. Some major Personal Entrepreneurial Characteristics

\begin{tabular}{|l|l|}
\hline \multicolumn{1}{|c|}{ Authors } & \multicolumn{1}{c|}{ The identified personal entrepreneurial characteristics } \\
\hline Ajzen (1991) & $\begin{array}{l}\text { Attitude towards a behaviour, subjective norms and perceived behav- } \\
\text { ioural control }\end{array}$ \\
\hline Caird $(1991 ; 2006)$ & $\begin{array}{l}\text { Calculated risk-taking, creative tendency }{ }^{1} \text {, high need for achievement, } \\
\text { high need for autonomy, and an internal locus of control. }\end{array}$ \\
\hline Rauch and Frese $(2007 ; 2012)$ & $\begin{array}{l}\text { Need for achievement, risk-taking, innovativeness, autonomy, locus of } \\
\text { control and self-efficacy. }\end{array}$ \\
\hline $\begin{array}{l}\text { Management Systems International } \\
\text { (MSI) cited in Reyes et al., (2018) }\end{array}$ & $\begin{array}{l}\text { Opportunity seeking, risk-taking, information seeking, systematic planning } \\
\text { and monitoring, persuasion and networking, commitment, persistence, de- } \\
\text { mand for efficiency and quality, goal-setting and self-confidence. }\end{array}$ \\
\hline
\end{tabular}

Source: own compilation.

Empirically, Greene et al. (2015) have identified entrepreneurship education as one of the major channels to propagate entrepreneurial engagements among the most affected population 'youth' by policymakers and key stakeholders. Entrepreneurship education is a major stride of the Nigerian government in promoting entrepreneurial intention among the youth. To enforce this policy, entrepreneurial education was introduced in 2006 as a compulsory component of undergraduate course requirement in Nigerian universities/tertiary institutions. More than a decade since the programme kicked off, there have been challenges and dissimilar views on the accomplishment of the policy. Notable challenges include misrepresentation of entrepreneurship education in different institutions. Some of tertiary institutions commonly presenting entrepreneurship education programmes within the context of vocational and technical education rather than developing the goal of stimulating entrepreneurship intent and interest in various disciplines. Other challenges include the theory-based approach of teaching the course.

Despite the challenges, studies have reported wide acceptance and adoption of entrepreneurial education. For instance, Ekundayo and Babatunde (2014) argue that entrepreneurial education and programs increase the students' attitudes and overall entrepreneurial intention among them. Similarly, Barba-Sánchez and Atienza-Sahuquillo (2018) claim that exposing engineering students to entrepreneurial education has a positive influence on their intention towards entrepreneurship. Further-

\footnotetext{
${ }^{1}$ Creative tendency is the tendency to be imaginative, innovative, curious and versatile, which requires both quantity and quality of ideas, together with flexibility and innovation in thinking.
} 
more, Botha et al. (2007) found that the special women entrepreneurial programme (WEP) was effective and positively influenced business start-up and venture creation among women in South Africa. Several authors have shown other factors as influencing entrepreneurial propensity among youths to include: entrepreneurial education (Hahn et al., 2020; Ayalew, 2020), supportive environment (Walter \& Block, 2016), and parents' entrepreneurial role (Liñán \& Fayolle, 2015; Olofinyehun, Adelowo \& Egbetokun, 2018; Hopp et al., 2019; Moussa and Kerkeni, 2021). Among the Hungarian students, Gubik (2021) found that positive entrepreneurial attitudes and better knowledge about entrepreneurship process has the chance to positively influence them towards entrepreneurship career. Also, Sołek-Borowsk and Numprasertchai (2018) assert that entrepreneurship education positively reinforces students' attitude towards entrepreneurship career choice in Thailand and Poland. The evaluation of entrepreneurship related courses and students' participation in three countries, as demonstrated in Gubik and Baartha (2018), further confirms that providing more efficient entrepreneurial activities in the university could spur competitive drive among them. Entrepreneurial education exposes young undergraduates to the nitty-gritty of business management and mentoring, where available. This equips them with better competence and confidence to take calculated business risk. The supportive environment includes the provision of entrepreneurship centres or tech hubs where business ideas can be nurtured to improve start-up potentials among them. Parents' entrepreneurial role/activity provides a justifiable ground for the offerings to become entrepreneurs, though not automatic.

\section{Briefs on Entrepreneurship Ecosystem in Nigeria}

In a bid to eradicate the menace of unemployment in Nigeria, different government administrations have launched programmes/policies to address the situation. The programmes/policies are all targeted at improving the economy by empowering the nation's undergraduates and youth to acquire entrepreneurial skills and become self-reliant and consequently employers of labour. Some of the government's initiatives and policies, through support agencies, include National Directorate for Employment (NDE), National Poverty Eradication Programme (NAPEP), Bank of Industry (BOI) Entrepreneurship Scheme, SAED; N-POWER, SURE-P, YES and YOUWIN, business incubation centres, Small, Medium Enterprises Development Agency (SMEDAN), National Office for Technology Acquisition and Promotion (NOTAP), Raw Materials \& Development Council (RMRDC), as well as compulsory entrepreneurial education for undergraduates, among others. These initiatives are set up to facilitate the establishment of ventures and small businesses to defeat the menace of poverty and unemployment (Akhuemonkhan, Raimi \& Sofoluwe, 2013; Emannuel, Dazala \& Daniel, 2012).

\section{RESEARCH METHODOLOGY}

This study adopts a cross-sectional research design. A questionnaire was used to collect data from undergraduates in six selected universities in Nigeria. This approach is deemed the most appropriate study design when study samples are multi-characterised and the sample size is large. A total of three thousand two hundred and seventy-seven $(\mathrm{N}=3,277)$ students in their second and fifth year from six universities participated in the study. The universities were purposively selected based on the depth of entrepreneurship programme they offer. For each university, six hundred copies of the questionnaire were administered across various disciplines. A single set of questionnaires, containing closedended questions, was deployed to elicit relevant information from the undergraduates. The personal entrepreneurial characteristics (PEC) of students were captured using a validated scale developed by Management System International in 2018 (Reyel et al., 2018). The scale was adapted and used to assess the entrepreneurial characteristics of undergraduates. The scale provided information on ten key indicators of PECs, including opportunity seeking, risk-taking, information seeking, systematic planning and monitoring, persuasion and networking, commitment, persistence, demand for efficiency and quality, goal-setting and self-confidence. In all, the students were asked to describe their PECs by responding to fifty-five (55) questionnaire items, which were scored on a five-point Likert scale ranging from 0 (never) to 4 (always). The scale validity produced a Cronbach's alpha of 0.918 , suggesting superb 
internal consistency and scale reliability. The mean scores were computed for analysis and a mean score above 2 is indicative of positive perception of students' entrepreneurial characteristics.

Furthermore, demographic information was requested of the students. Students were asked whether they had attended or taken an entrepreneurship education course as part of their undergraduate studies. This was a dichotomous response of either 'Yes' or 'No'. In order to measure the undergraduates' entrepreneurial interest, a dichotomous question of whether they were interested in starting a business or not was included in the questionnaire. Other important variables of interest included parents' business experience and basic background information.

Data were analysed using descriptive and inferential statistics. Weighted average mean scores were computed from the responses to PECs items. The mean scores were rated and ranked for each of the ten indicators. These ten indicators were later used as the independent variables for the binary logistic regression analysis conducted showing the extent to which the PECs defined entrepreneurial interest. The binary logistic regression provides deeper information about the degree and direction of influence of independent variables on the dependent variables. Furthermore, some control variables were introduced to estimate how parental entrepreneurial activities and entrepreneurship courses taken by the students influence their entrepreneurial potential. These two variables tend to shape students' entrepreneurial perspectives and behaviour. The results of the analyses are presented in tables and are discussed in the subsequent part of the paper.

\section{RESULTS AND DISCUSSION}

The personal entrepreneurial characteristics of respondents are described using 10 entrepreneurial traits developed and validated by Management System International, cited in Reyes et al. (2018). Using the mean score analysis, goal-settings (3.09), information seeking (2.88) and self-confidence (2.81) are revealed as the most occurring entrepreneurial characteristics among undergraduates of Nigerian universities. While the least occurring personal entrepreneurial characteristics among the undergraduates are risk-taking (2.42), opportunity recognition (2.41) and demand for recognition (2.53). Summarily, the majority of the undergraduates sampled scored high on the personal entrepreneurial characteristics scale with a mean score of 2.66 , suggesting that the students' trait/character could potentially predispose them to entrepreneurship. Innate entrepreneurial characteristics serve as push factors in driving entrepreneurial engagement. Similarly, traits such as risk-taking and self-confidence coupled with an enabling environment propel an individual to engage in entrepreneurial activities with the goal of self-actualisation and high need for self-fulfilment.

To improve entrepreneurial thinking and encourage start-up potential among students, the low risk taking ability is one key area where attention is required.

Table 2. Personal entrepreneurial characteristics of undergraduates in Nigeria

\begin{tabular}{|l|c|}
\hline \multicolumn{1}{|c|}{ Variables } & Mean \\
\hline Goal-setting & 3.09 \\
\hline Information seeking & 2.88 \\
\hline Self-confidence & 2.81 \\
\hline Systematic planning & 2.62 \\
\hline Commitment & 2.60 \\
\hline Persistence & 2.65 \\
\hline Persuasion and networking & 2.63 \\
\hline Demand for recognition & 2.53 \\
\hline Opportunity recognition & 2.41 \\
\hline Risk-taking & 2.42 \\
\hline Average mean & $\mathbf{2 . 6 6}$ \\
\hline
\end{tabular}

Key: Never $=0$, rarely $=1$, sometimes $=2$, usually $=3$ and always $=4$.

Source: own study. 
Binary logistic regression analysis was employed to test the dynamic relationship between personal entrepreneurial characteristics (PECs) and the start-up potentials among the students using the mean scores computed from the PECs as the independent variables. The results show that students with high goal-setting characteristics are more likely to engage in start-ups (OR=1.79, $p<0.001)$. This result suggests that students with great ability to set goals and pursue them have greater triggers for entrepreneurship potential. In fact, one critical quality of an entrepreneur is the ability to set realistic goals and pursue them. This trait can be placed within the perceived behavioural control of Ajzen (1991), such that the confidence to succeed is demonstrated in the competence to set realistic goals, including entrepreneurial. The results corroborate those of Reyes et al. (2018), who demonstrated through Spearman's rank correlation that goal-setting is a significant indicator of entrepreneurial intention among undergraduate students in the Philippines.

Further results show that students with opportunity recognition abilities are more likely $(O R=1.36$, $p<0.1$ ) to be predisposed to entrepreneurship activities. Opportunity recognition potential has been established as the ground base for entrepreneurship, and therefore the potential to recognise opportunity in the midst of challenges and chaos is a critical trait of a potential entrepreneur.

Table 3. Binary logistic regression showing relationship between start-up potentials among undergraduates and other explanatory variables

\begin{tabular}{|l|c|c|c|c|}
\hline Variables & Exp (B) & 95\% confidence interval & Sig & S.E \\
\hline Risk-taking & 1.146 & $0.829-1.584$ & 0.411 & 0.165 \\
\hline Opportunity recognition & 1.360 & $0.956-1.933$ & 0.087 & 0.180 \\
\hline Commitment & 0.750 & $0.530-1.060$ & 0.103 & 0.177 \\
\hline Persistent & 1.068 & $0.743-1.535$ & 0.723 & 0.185 \\
\hline Demand for recognition & 0.979 & $0.674-1.422$ & 0.910 & 0.191 \\
\hline Goal-setting & 1.790 & $1.329-2.411$ & 0.000 & 0.152 \\
\hline Information seeking & 1.103 & $0.795-1.532$ & 0.557 & 0.167 \\
\hline Systematic planning & 0.943 & $0.662-1.344$ & 0.747 & 0.181 \\
\hline Persuasion and networking & 1.160 & $0.836-1.611$ & 0.374 & 0.167 \\
\hline Self-confidence & 0.983 & $0.708-1.363$ & 0.916 & 0.167 \\
\hline Parents' business involvement & 3.364 & $0.212-0.417$ & 0.000 & 0.173 \\
\hline Student's entrepreneurial education & 1.813 & $0.414-0.734$ & 0.000 & 0.146 \\
\hline
\end{tabular}

-2 Log Likelihood $=1429.64$, Nagerlkerke R square $=0.093$, Hosmer and Leshow Test $=0.802$.

Source: own study.

Cultivating this trait through entrepreneurship education tends to improve students' locus of control and promote venture creation (Bae et al., 2014; Olofinyehun et al., 2018). Other PECs such as persuasion and networking $(O R=1.16, p>0.1)$ and risk taking $(O R=1.146, p>0.1)$ also predispose the students to entrepreneurship interest; however, the results were not significant. Persuasion and networking traits in students are seen to positively determine entrepreneurial interest from the analysis, justifying the self-motivation components of entrepreneurs. Certain characteristics or traits of entrepreneurs are better expressed than explained, such is the persuasion that a particular course of action is strongly pursued based on personal conviction.

Moreover, the results further showed that students whose parents have business experience are highly more likely $(O R=3.364, p<0.001)$ to start a business and students who have taken entrepreneurship education are $81 \%$ more likely $(O R=1.813, p<0.001)$ to run a business even as undergraduates. The results corroborate the impacts of parental influence and entrepreneurship education on the entrepreneurial interest of the offspring/students (Hahn et al., 2020; Ayalew, 2020; Moussa \& Kerkeni, 2021). Shirokova et al. (2016) also showed how family background of students positively influenced their entrepreneurial inclinations. The logic is straightforward as individuals whose parents operate one form of business or the other tend to be exposed to such business from a tender age. In fact, some parents deliberately prepare their offspring for business succession at a tender age through appropriate mentoring schemes (see also Liñán \& Fayolle, 2015; Hopp et al., 2019). Exposing students to entrepreneurship education tends to ignite the passion for entrepreneurship 
in them; however, it has also been argued that $E E$ is not a sufficient condition for promoting entrepreneurship within an ecosystem (Rippa et al., 2020).

\section{CONCLUSIONS}

This study has focused on a critically important question regarding the extent to which the personal entrepreneurial characteristics (PECS) of the youth in Nigerian higher education institutions have influenced their entrepreneurial inclination. It further reinforced the established roles of entrepreneurship education and family influence on the entrepreneurial potential of the youth in the universities. Previously, some key important correlates of entrepreneurial intentions among youths include age, gender, national entrepreneurial ecosystem, family support, $\mathrm{EE}$, and more importantly mentoring process were not identified. In this study, some important personal characteristics of students at universities that serve as indicators to entrepreneurial development need to be adequately targeted if the entrepreneurship education policy will achieve its desire goals. The goal-setting and opportunity recognition potential ability of students need to be adequately built or sustained to enhance entrepreneurial performance among them. Building students' opportunity recognition potential is indeed important to the foundation of entrepreneurial development in developing countries, Nigeria in particular. To develop opportunity-driven entrepreneurship is much more profitable for nations than what we currently experience in Africa, where necessity-driven entrepreneurship is at the order of the day (Global Entrepreneurship Monitor ((GEM), 2019/2020). The growth potential of opportunity-driven entrepreneurship is identified to be far-reaching rather than necessity-driven. More so, the curriculum for entrepreneurship education in the country should be tailored towards building the critical skills necessary for stimulating entrepreneurship across all universities, including goal-setting and opportunity recognition. These two factors are highly significant and predispose them to entrepreneurship. Introduction of practical business internship and mentoring processes into the EE have greater tendency to demonstrate real-life actions to sustain/improve students' entrepreneurial interest. Therefore, each university could modify the entrepreneurship education curriculum to accommodate practical or business simulation and venture mentoring processes. The establishment of innovation facilities such as business incubators, science parks, tech-hubs, and accelerators should be seriously pursued by the government and university administrators to promote and stimulate the entrepreneurship potentials of the students. For instance, most technopreneurs operating in the booming Nigerian tech-hubs across the country are mostly graduates of higher institutions, who at some point must have been exposed to compulsory entrepreneurship education. Furthermore, the ICT cluster in Lagos Nigeria, popularly known as Otigba, is another initiative to create a conducive atmosphere for businesses to thrive with spill-over effects on other sectors of the economy. Today, the Otigba computer village is renowned for huge ICTs activities to optimise production and adaptation. University administrators could replicate Otigba in the university environment by creating clusters around areas of expertise to engage students with high entrepreneurial intentions and positive entrepreneurial characteristics. Synchronising entrepreneurship education policy with science technology and innovation policy could further bolster entrepreneurship among students and faculties in the national research system thereby enriching the innovation ecosystem in the country.

The study is not without limitation. A cross-sectional data was used in the study to estimate how PECs and EE influenced entrepreneurship propensity among the students. This interest may change over time and a longitudinal data would have provided a better analysis to really monitor how their PECS changes as EE becomes more intense. Moreso, to better understand the impact of EE on entrepreneurial propensity, an experimental or quasi-experimental analysis would have provided a better result. In addition, context matter, therefore, the results should be carefully interpreted to avoid overgeneralisation.

\section{REFERENCES}

Adebayo, A.A. (2013). Youth unemployment and crime in Nigeria: Implications for national development. International Journal of Sociology and Anthropology, 5(8), 350-357. https://doi.org/10.5897/IJSA 2013.0452 
Adelowo C.M., Egbetokun, A.A., \& James A.O. (2016). Who wants to be an entrepreneur and why? A study of highly educated young Nigerians. A paper presented during Research Workshop for Grant Holders Organised by the Centre for Economic Policy Research (CEPR) 14-15 March 2016, London.

Adelowo, C.M., Joshua, A., \& Ilevbare, O.E. (2018). Entrepreneurship Potentials among Undergraduates in Nigerian Universities: Empirical Evidence. AMC Indian Journal of Entrepreneurship, 1(2).

Ajzen, I. (1991). The Theory of Planned Behavior. Organizational Behavior and Human Decision Processes, 50 (2), 179-211.

Ajzen, I., \& Fishbein, M. (2005). The influence of attitudes on behaviour (pp. 173-221). In D. Albarracín, B.T. Johnson, \& M.P. Zanna (Eds.), The handbook of attitudes. Lawrence Erlbaum.

Akhuemonkhan, I.A, Raimi, L., \& Sofoluwe, A. (2013) Entrepreneurship Education and Employment Stimulation in Nigeria. Journal of Studies in Social Sciences, 3(1), 55-79.

Ayalew, M. M. (2020). Bayesian hierarchical analyses for entrepreneurial intention of students. Journal of Big Data, 7(1), 1-23.

Bae, T.J., Qian, S., Miao, C., \& Fiet, J.O. (2014). The relationship between entrepreneurship education and entrepreneurial intentions: A meta-analytic review. Entrepreneurship Theory and Practice, 38(2), 217-254.

Barba-Sanchez, V., \& Sahuquillo, C.A. (2018). Entrepreneurial Intention among Engineering Students: The Role of Entrepreneurship Education. European Research on Management and Business Economics, 24(1), 53-61.

Ben Moussa, N., \& Kerkeni, S. (2021). The role of family environment in developing the entrepreneurial intention of young Tunisian students. Entrepreneurial Business and Economics Review, 9(1), 31-46. https://doi.org/10.15678/EBER.2021.090102

Botha, M., Nieman G., \& Vuuren, J. (2007). Measuring the effectiveness of the women entrepreneurial programme on potential, start up and established women entrepreneurs in South Africa. South African Journal of Economic and Management Sciences, 10 (2), 163-183.

Caird, S. (2006). General measure of enterprising tendency version 2 (GET2). In T. Mazzarol (Ed.), Entrepreneurship and Innovation. Prahran, VIC: Tilde University Press, 247-266.

Caird, S., (1991), The enterprising tendency of occupational groups. International Small Business Journal, 9(4), 75-81.

Ekundayo, B.B., \& Babatunde, E.D. (2014). The impact of entrepreneurship education on entrepreneurial intentions among Nigerian undergraduates. International. Journal of Research in Humanities, Arts and Literature, 2(11), 15-26.

Emmanuel, E.A., Dazala, I.U., \& Daniel, J.D. (2012). Entrepreneurship Education and Attitude of Undergraduate Students to Self-Employment in Mubi, Adamawa State, Nigeria. Journal of Education and Practice, 3(8), 95-97.

Gartner, W.B. (1989). Who is an entrepreneurs? is the wrong question. Entrepreneurship Theory and Practice, 12(2), 47-68.

GEM (2019). Global Entrepreneurship Monitor Report 2019/2020. London: Global Entrepreneurship Research Association.

GEM (2020). Global Entrepreneurship Monitor Report 2019/2020. London: Global Entrepreneurship Research Association, London Business School.

Greene, P.G., Brush, C.G., Eisenman, E.J., Neck, H., \& Perkins, S. (2015). Entrepreneurship education: A global consideration from practice to policy around the world. A publication of World Innovation Summit for Education, Qatar.

Gubik, A.S. (2021). Entrepreneurial career: Factors influencing the decision of Hungarian students. Entrepreneurial Business and Economics Review, 9(3), 43-58. https://doi.org/10.15678/EBER.2021.090303

Gubik, A.S., \& Bartha, Z. (2018). The role of university in influencing the entrepreneurial intention of university students. International Entrepreneurship Review, 4(3), 177-188. https://ier.uek.krakow.pl/index.php/pm/article/view/1770

Gürol, Y., \& Atsan, N. (2006). Entrepreneurial characteristics amongst university students: Some insights for entrepreneurship education and training in Turkey. Education + Training, 48(1), 25-38. https://doi.org/10.1108/00400910610645716

Hahn, D., Minola, T., Bosio, G., \& Cassia L. (2020). The impact of entrepreneurship education on university students' entrepreneurial skills: a family embeddedness perspective. Small Business Economics, 55 (1), 257-282. https://doi.org/10.1007/s11187-019-00143-y 
Hayek, F.A. (1945). The Use of Knowledge in Society. American Economic Review, 35(4), 519-530.

Holienka M., Holienková, J., \& Gál, P. (2015). Entrepreneurial Characteristics of Students in Different Fields of Study: A View from Entrepreneurship Education Perspective. Acta Universitatis Agriculturae et Silviculturae Mendelianae Brunensis, 63(6), 1879-1889.

Hopp, C., Minarikova, D., \& Speil, A. (2019). A chip off the old block? How parent-child interactions affect the intergenerational transmission of entrepreneurial intentions. Journal of Business Venturing Insights, 11, e00130. https://doi.org/10.1016/j.jbvi.2019.e00130

Igwe C.N., Adebayo, M.S., Olakanmi, O. A., Ogbonn, I.G., \& Aina, O.S. (2013). Promoting Wealth and Job Creation in Nigeria- Review of the role of Entrepreneurship. Journal of Sustainable Development Studies, 3(1), 80-100.

Kigotho, W. (2015). Producing unemployable graduates wastes time and money. University World News, 359, 1-3.

Knight, F.H. (1921). Risk, Uncertainty and Profit. Boston, MA: Houghton Mifflin.

Linan, F., \& Fayolle, A. (2015). A systematic literature review on entrepreneurial intentions, thematic analyses, and research agenda. International Entrepreneurship and Management Journal, 11(4), 907-933. https://doi.org/10.1007/s11365-015-0356-5

Lumpkin, G.T., \& Dess, G.G. (1996). Clarifying the Entrepreneurial Orientation Construct and Linking it to Performance. Academy of Management Review, 21(1), 135-172. http://dx.doi.org/10.2307/258632.

Lumpkin, G.T., \& Dess, G.G. (2001). Linking two dimensions of entrepreneurial orientation to firm performance: The moderating role of environment and industry life cycle. Journal of Business Venturing, 16(5), 429-451. https://doi.org/10.1016/S0883-9026(00)00048-3

Maina, R.W. (2011). Determinants of entrepreneurial intentions among Kenyan college graduates. KCA Journal of Business Management, 3(2), 1-18. https://doi.org/10.4314/kjbm.v3i2.65968

Mclrelland, U.C. (1961). The achieving society. New York: New York Free Press

NBS (2018). Report, Labour Force Statistics: Unemployment and Underemployment Report Q4 2017-Q3 2018. National Bureau of Statistics.

NBS (2020). Labor Force Statistics: Unemployment and Underemployment Report (Q2 2020). National Bureau of Statistics, Abridged Labour Force Survey Under Covid-19. National Bureau of Statistics (NBS), Abuja. Retrieved from https://www.nigerianstat.gov.ng/pdfuploads/Q2_2020_Unemployment_Report.pdf on 20 July 2021.

Olofinyehun, A., Adelowo, C., \& Egbetokun, A. (2018). The Supply of High Quality Entrepreneurs in Developing Countries: Evidence from Nigeria. Science and Public Policy, 45(2), 269-282.

Olomi, D.R., \& Sinyamule, R.S. (2009). Entrepreneurial inclinations of vocational education students: A comparative study of male and female trainees in Iringa region, Tanzania. Journal of Enterprising Culture, 17(1), 103-125.

Pinelli, M. (2015). Can entrepreneurship solve the youth unemployment crisis? Retrieved from https://www.weforum.org/agenda/2015/09/can-entrepreneurship-solve-the-youth-unemployment-crisis/ on 27 April 2021.

Rauch, A., \& Frese, M. (2007). Let's put the person back into entrepreneurship research: A meta-analysis on the relationship between business owners' personality traits, business creation, and success. European Journal of Work and Organizational Psychology, 16(4), 353-385. https://doi.org/10.1080/13594320701595438

Rauch, A., \& Frese, M. (2012). Entrepreneurship as a Key Element in Advancing the Psychology of Competitive Advantage. Industrial and Organizational Psychology, 5(1), 108-111. https://doi.org/10.1111/j.17549434.2011.01414.x

Reyes, G.U., Mariano, R.A., Herrera, M.N.Q., Manipol, N.E.P., \& Cabardo, J.J.S. (2018). Personal Entrepreneurial Competencies and Entrepreneurial Intention of Non-Business Students Enrolled in an Introductory Entrepreneurship Course. Journal of Economics, Management and Agricultural Development, 4(1), 93-102.

Rippa, P., Ferruzzi, G., Holienka, M., Capaldo, G., \& Coduras, A. (2020) What drives university engineering students to become entrepreneurs? Finding different recipes using a configuration approach. Journal of Small Business Management, https://doi.org/10.1080/00472778.2020.1790291

Schumpeter, J.A. (1934). The Theory of Economic Development. Harvard Economic Studies.

Schumpeter, J.A. (1942). Capitalism, Socialism and Democracy. London: Allen and Unwin.

Shirokova, G., Osiyevskyy, O., \& Bogatyreva, K. (2016). Exploring the intention-Behaviour link in student entrepreneurship: Moderating effects of individual and environmental characteristics. European Management Journal, 34(4), 386-399. https://doi.org/10.1016/j.emj.2015.12.007 
Siyanbola W.O, (2011). Framework for Technological Entrepreneurship Development: Key Issues and Policy Directions. American Journal of Industrial and Business Management, 1(1), 10-19. https://doi.org/10.4236/ajibm.2011.11002

Souitaris, V., Zerbinati, S., \& Al-Laham, A. (2007). Do entrepreneurship programmes raise entrepreneurial intention of science and engineering students? The effect of learning, inspiration and resources. Journal of Business Venturing, 22(4), 566-591. https://doi.org/10.1016/j.jbusvent.2006.05.002

Sołek-Borowska, C., \& Numprasertchai, H. (2018). Exploring entrepreneurial intentions of students: international perspective. International Entrepreneurship Review, 4(3), 357-372. Retrieved from https://ier.uek.krakow.pl/index.php/pm/article/view/1779 on 1 August 2021.

Titley, J., \& Anderson-Macdonald, S. (2015). When entrepreneurship training matters most. International Growth Centre Blog. Retrieved from https://www.theigc.org/blog/when-entrepreneurship-training-matters-most/ on 8 February 2021

USAID (2011). The entrepreneurship toolkit Successful approaches to fostering Entrepreneurship. Business Growth Initiative Publication.

Walter, S.G., \& Block, J.H. (2016). Outcomes of entrepreneurship education: An institutional perspective. Journal of Business Venturing, 31(2), 216-233. https://doi.org/10.1016/jjbusvent.2015.10.003.

World Bank (2020). The Human Capital Index 2020 Update: Human Capital in the Time of COVID-19. Washington, DC: World Bank. https://openknowledge.worldbank.org/handle/10986/3443

World Bank (2019). Nigeria Economic Update: Accelerating Economic Expansion, Creating New Job Opportunities. Retrieved from https://www.worldbank.org/en/country/nigeria/publication/nigeria-economic-update-accelerating-economic-expansion-creating-new-job-opportunities on 20 July 2021.

Wu, S., \& Wu, L. (2008). The Impact of Higher Education on Entrepreneurial Intentions of University Students in China. Journal of Small Business and Enterprise Development, 15(4), 752-774. https://doi.org/10.1108/14626000810917843 


\section{Authors}

All three authors were jointly responsible for drafting the manuscript. C.M. Adelowo and O. llevbare obtained, analysed and interpreted the data. J. Surujlal critically revised the manuscript for submission.

\section{Caleb M. Adelowo}

PhD in Technology Management (2017) Obafemi Awolowo University, Nigeria; MSc Technology Management (2014), Obafemi Awolowo University; Master's degree in Intellectual Property (2010), Africa University, Zimbabwe, BSc Accounting (2008) Obafemi Awolowo University, Nigeria. His research interests include Entrepreneurship and innovation management, intellectual property management, technology transfer and commercialisation, organisational behaviour.

Correspondence to: Dr. Caleb M. Adelowo, Postdoctoral Fellow, Faculty of Economic and Management Sciences, North-West University, Potchefstroom, South Africa, e-mail: caleb.adelowo@nacetem.gov.ng; calebakinrinade@yahoo.com

ORCID $\odot$ http://orcid.org/0000-0002-4578-5708

\section{Oluwatosin E. llevbare}

PhD in Psychology (2018), Obafemi Awolowo University, Nigeria; MSc Psychology, (2013), Obafemi Awolowo University, Nigeria; BSc Psychology, (2007), Obafemi Awolowo University, Nigeria. Her research interests include health behaviour, entrepreneurial studies and adoption of innovation.

Correspondence to: Dr. Oluwatosin E. Ilevbare, National Centre for Technology Management, lle-Ife, Nigeria, e-mail: psytosin@yahoo.com

ORCID $\odot$ http://orcid.org/ 0000-0001-6263-6758

\section{Jhalukpreya Surujlal}

PhD in Sport Management (2003), University of Johannesburg, South Africa; Master's in Public Administration (MPA), University of KwaZulu-Natal, South Africa; BCom, University of South Africa (UNISA). His research interests are human resource management, sport management, marketing and entrepreneurship.

Correspondence to: Dr. Jhalukpreya Surujlal, Faculty of Economic and Management Sciences, North-West University, Potchefstroom, South Africa, e-mail: Babs.Surujlal@nwu.ac.za

ORCID $\odot$ http://orcid.org/0000-0003-0604-4971

\section{Acknowledgements and Financial Disclosure}

The authors acknowledged PEDL Research Team (ERG\#3155) for making the data available to the authors. Data used were collected by the Team (Adelowo, Egbetokun and James) in 2016.

\section{Conflict of Interest}

The authors declare no conflict of interest.

\section{Copyright and License}

This article is published under the terms of the Creative Commons

Attribution - NoDerivs (CC BY-ND 4.0) License

http://creativecommons.org/licenses/by-nd/4.0/ 